\title{
3. THEORETICAL CONSIDERATIONS ON SKILLS FOR FINE ARTS
}

\author{
Ana-Maria Aprotosoaie-Iftimi ${ }^{202}$
}

\begin{abstract}
Every person has many qualities that help him/her to obtain more or less good results in different fields of activity. Some easily get good results in drawing or gymnastics, others easily learn math or languages. Generally, when a child achieves high performance in a field he/she is said to have skills. Knowing the skills specific to the field, identifying them in the process of guiding the child, their development and refinement are evolutionary aspects to be neglected in educational practice.
\end{abstract}

Key words: skills, abilities, predispositions, fine arts, education

\section{Conceptual delimitations}

According to one of the first human resources companies in Romania (BIA. HR, 2015) knowledge, aptitudes, abilities and acquired skills are four distinctive elements in that some derive from innate qualities and others are acquired, either through theoretical learning or through experience accumulated over time. According to Decision no. 918/2013 on the approval of the National Qualifications Framework. Annex 1. In the Official Gazette. Part I. Nr. 734 knowledge represents the theoretical or practical understanding of some principles, processes and general concepts in a certain field of work or study (Decision no. 918/2013 on the approval of the National Qualifications Framework). For example, we can talk about mathematical, scientific knowledge. They have a formative role helping both the development of mental processes and the formation of skills which leads to the assimilation of new acquisitions.

A large volume of knowledge does not imply the existence of an aptitude or skill (Luca, 2010). Aptitudes, useful in performing specific tasks, can be developed with the continuous accumulation of experience, information and notions. The term aptitude comes from Latin, from the word "aptus" which means "good for", "capable of". According to Sillamy (1998), aptitude is "a natural and acquired disposition to perform certain tasks" (p. 33). On the other hand, aptitude is seen as "an individual psychic trait that conditions the fulfillment in good conditions of a work, of an action; application, inclination, is a natural or earned disposition to do some things" (Small encyclopedic dictionary. 3rd edition revised and added, 1986, p.81). Aptitudes, from Richelle's (2006) point of view, "are relatively stable individual characteristics, resulting from over-learning or they are genetically determined and they are identified by success in the activity" (p.81). Zlate (2000) defines skills as "a complex of processes, psychic traits, individual structured in an original way, which allows the successful performance of certain activities" (p.258). Thus, skills can be seen as physical or mental tools and represent the executive and instrumental side of the personality. That mental

${ }^{202}$ Lecturer PhD., "George Enescu" National University of Arts from Iaşi, Romania, email: anamariaiftimi@gmail.com 
trait that allows the student to achieve superior performance in the activity can be considered an aptitude. Therefore, skills are "qualities of the person who, as a whole, explain the differences found between people in terms of the ability to acquire certain knowledge, skills and abilities" (Cosmovici, A., 1974, p. 115, apud Bălan, 1999, p. 71).

Although the term "aptitude" is synonymous with "capacity" and "ability", there is still a fairly fine line between aptitudes and abilities, which is why the two notions are often confused. According to some opinions, the main difference between the two would be that aptitudes are acquired (Zlate, 2000, p. 263), and abilities are innate (Luca, 2010, p.22). By definition, skills are a "circumscribed set of competencies that are updated in effective behaviors and which, in general, are the result of learning favored by innate dispositions or skills" (Richelle, 2006, p. 15), which means they are positive qualities, they may or may not exist in a student's profile and could be defined by how well he/she knows how to implement knowledge, develop and improve skills. There are several types of aptitudes: grace (the ability to achieve superior performance, makes it possible to create new and original values - Zlate, 2000) and aptitudes acquired in school and that can be used in new activities outside of school, called transferable. Aptitudes and abilities have different degrees of transferability. Some of them can be transferred to a limited number of activities, and others can be applied to a larger number, that is they are more general (writing, reading, using a computer). The aptitudes developed in school can be transferred for various extracurricular and later professional activities. Viewed as acquired motor aptitudes, declarative and procedural knowledge, aptitudes, through application in practice, become acquired skills, and their lack does not always mean the absence of an aptitude (Luca, 2010).

It is important to demonstrate that by building skills and abilities you can use your personal potential, i.e. to know how you can use your knowledge to perform well in an activity. According to Bălan (1999) the psychic capacity "expresses the possibility of the individual to successfully perform a certain activity here and now. It is always connected to the present moment and is deeply influenced by the experience in that field" (p. 70). Unlike capacity, aptitude is linked, in essence, to the possibility that in the event of ensured optimal conditions, the student will reach the acquisition of a high capacity in a field. This is especially important for a teacher if we consider that most of the time students are not evaluated according to their aptitudes but according to their abilities. The direct evaluation of the aptitudes is done by evaluating the performances at certain tests, therefore of the capacities. Bălan (1999) considers that what indicates the level of aptitude development would be:

- the ease with which the student learns (reduced time and effort invested into it); - the quality of learning.

Each of us has aptitudes in a certain field, but about the person who possesses an aptitude at a higher level of development than most other individuals, we can say that he/she is talented. Zisulescu (1971) considers that talent is a superior stage of aptitude development, being characterized not only by the successful 
completion of an activity but also by the power to create original works. The two notions, talent and grace are easy to confuse with one another. Aptitude allows the achievement of differentiations between individuals. If all normally developed people possess a certain characteristic, then this is no longer an aptitude. The criteria by which an aptitude is distinguished is the effort with which the person performs a certain activity and the speed of accomplishing the activity. Bonchiss (2000) identifies three characteristics that indicate the presence of aptitudes: superiority in performance, precocity in appearance and continuity in progress under the influence of stimulation and exercise. Cretu (2011) appreciates that aptitudes are manifested with an increased openness to the corresponding categories of stimuli, with the rapid retention of significant information, as an easy mastery of simple practical movements and actions. Research has shown that most aptitudes have a normal distribution in the population. For example, the ability to draw is very well developed or not at all for a small number of people, while most draw at a mediocre level. Each individual has many aptitudes, some of which are good, others mediocre or poorly developed (for example, someone is very intelligent, but has mediocre manual dexterity, and his aptitude for music is very poor).

The question arises as to whether aptitudes are innate or acquired. Psychologists want to know to what extent a psychic function (e.g. the aptitude for graph) is innate, and to what extent it can be influenced, modified by the environment. Some psychologists, for example Helen Bee (1997, apud. Bălan, 1999, p.71) claim that aptitudes have a biological, innate character, i.e. they can be inherited or can be learned from childhood, more precisely from activities carried out during school time. For example, in the case of graphic skills, a very well developed vision would be an anatomical-physiological element. Also, another example would be that of intelligence, as a general aptitude, which is an important hereditary component, and this component is related to the basic neurological functioning of the brain. Bălan (1999) considers that aptitudes are the results of environmental influences, from early childhood. For example, it has been found that by the age of 8 months children are able to discriminate all possible linguistic sounds in all languages of the globe. Gradually, within 1-2 years, the child loses the ability to recognize sounds other than those specific to the language he hears around him. Also, if one of your parents is an artist, you are more likely to have artistic aptitudes because you live with an artist. Likewise, if you get involved in artistic activities from your childhood, you can develop artistic aptitudes (without having hereditary ones). In general, students have interests in the areas in which they have aptitudes, because they can develop their aptitudes more easily, which motivates them to progress.

The level of development of the aptitudes can be established by "measuring" them with the help of tests and reporting the results obtained to the results of the population to which the subject belongs. When we determine the level of development of a person's skills, we say that we make up his aptitude profile. The aptitude profile can be used in school or career guidance activities. Aptitudes are based on predispositions, hereditary premises contained in the genetic equipment 
of the individual (Jalley \& Richelley, 2006). Predispositions cannot be known. Predispositions are innate. Due to biological, psychological, social and cultural factors, predispositions can be transformed into skills and aptitudes into personal abilities. These can only be deduced from the results obtained in the activity. The presence of predispositions and skills is indicated by the ease with which knowledge is acquired, the aptitudes in a certain field and the very good results obtained by the individual in the activity. The precocity of manifesting an aptitude is another indication of the existence of native predispositions (some children learn to read from the age of 3-4 years, others obtain remarkable results in music or gymnastics from a very young age). The factors that ensure the transformation of predispositions into aptitudes and their capitalization into activity can be divided into factors related to the child and factors related to the environment. A negative action of biological, psychological, human group, cultural conditions and causes can stop the beneficial development of predispositions or even cause their destructuring. Among the factors related to the child we mention:

- how the child's aptitudes interact. Example: a colorblind child but with a sense of proportion and intelligence will not become a great painter because he does not have a sense of color.

- how aptitudes interact with personality traits: motivation, desire for selfrealization, interests, self-confidence, perseverance. Some people manage to get good results in an activity even if they do not have special aptitudes.

Some less developed skills can be offset by other aptitudes or by ambition, perseverance. At school, sometimes students with a lower intellectual level get better results than very intelligent students because they are more persevering. Other very well-endowed people "by nature" do not have great results in an activity, because they are not well motivated, they are not persevering.

- the child's activity, through which he acquires the necessary knowledge and skills.

The most important environmental factors are:

- the stimulating attitude of the family or other significant people for the child, for example teachers;

- economic, hygienic conditions, food;

- the particularities and demands of the socio-cultural environment that favor certain professional, artistic, scientific activities. Example: 100 years ago it would not have been possible to talk about computer skills. The same predispositions would have turned into another aptitude that would have manifested itself in another field.

\section{Discussions} 2017):

Aptitudes can be classified according to several criteria (Alexandrescu,

$\square$ Depending on the nature of the mental processes involved, the skills can be:

- sensory aptitudes: visual, auditory acuity, ability to differentiate chromatic nuances, musical hearing, etc .; 
- psychomotor aptitudes that require the coordination of psychic functions with movements. Such an aptitude is the perceptual-motor function which is manifested by the perception of movements or a drawing and their reproduction.

This function has a very important role for drawing, gymnastics or writing aptitudes;

- intellectual aptitudes: the ability to memorize, to focus attention, the aptitude for mathematics or grammar, intelligence.

$\square$ Depending on the degree of specialization, aptitudes can be (Cosmovici, 1974, apud Bălan, 1999, p.72):

- simple aptitudes are those that favor the accomplishment of numerous activities

- general aptitudes that are needed in most areas of activity: the spirit of observation, the ability to memorize, attention, inventiveness, intelligence;

- group aptitudes that allow the successful accomplishment of a small group of activities;

- specific aptitudes - characteristic of a single field of activity.

- special, complex skills that are needed to achieve good results in a certain field: sports, music, fine arts, etc.; a special aptitude can crystallize several simple aptitudes. For example, mathematical aptitude crystallizes numerical aptitude and intelligence. Examples of other special aptitudes: musical, literary, constructivetechnical, artistic, pedagogical, scientific, sports, organizational aptitudes.

Any group aptitude can be involved in building more complex aptitudes. For example, the capacity for spatial representation can interfere with the aptitude for architecture, mechanics or even anatomy. When analyzing aptitudes, the psychologist or teacher is guided by the structure of mental functions, studying general and group aptitudes. There are 6 group aptitudes (Bălan, 1999):

- the verbal factor, namely the individual's ability to quickly understand the meaning of words and phrases;

- the verbal fluency factor which consists in the individual's ability to understand expressions, verbal expression;

- the perceptual factor that consists in the individual's ability to perceive objects quickly and in detail;

- the numerical factor that consists in the individual's ability to operate with numbers;

- the factor of spatial representation which consists in the individual's ability to imagine objects in two and three-dimensional coordinates, to operate their movements or transformations in the mental plane (this factor helps to learn geometry);

- the manual dexterity factor which represents the ability to use objects, to handle various tools or imstruments (this factor helps in school and professional orientation).

Complex aptitudes (Bălan, 1999) are divided into 3 main categories:

- Technical aptitudes that lead to the possibility of using tools, machines and devices, to understand how to compose them or to build them. The perceptual factor, spatial representation and manual dexterity, as well as general intelligence are involved in these skills. In the construction of these aptitudes an essential role 
is played by the child's interest in such activities, environment or life, sex (usually boys have such skills), social mechanisms for determining gender roles (when children are offered cars, airplanes, construction games - we can determine the development of these aptitudes).

- Scientific aptitudes are those specific to a science. A special role in structuring these aptitudes is played by creativity, intelligence, temperament, as well as the group factors specific to that science.

- Artistic aptitudes represent the inclination towards a certain artistic field.

The teacher's task consists first of all in the individualized knowledge of the level of development of the abilities of each student, then in the adaptation of the content and of the didactic methods according to them, thus ensuring the efficiency of the educational approach. One of the most complex taxonomy regarding aptitudes is given by E.A. Fleishman (Andrieș, 2010) and refers to the division into 5 categories with examples specific for art education:

- cognitive aptitudes: comprehension and expression both verbally and in writing, memorization ability, inductive and deductive reasoning, originality, flexibility in thinking, spatial orientation, ability to visualize.

- psychomotor aptitudes: coordination and synchronization of movements, dexterity, precision.

- physical aptitudes: strength, coordination, endurance.

- sensory / perceptual aptitudes: visual acuity, chromatic, stereoscopic vision (focusing on an object to obtain a three-dimensional image), in depth

- social / interpersonal aptitudes: behavioral flexibility, sociability, responsibility.

The ability to draw and paint is a specific aptitude. Students with such aptitudes succeed:

- to imprint the visual images of the objects in their minds precisely, quickly and sustainably;

- show the tendency to fixate the whole with a lower inclination towards analysis;

- correctly appreciates deviations from the vertical or horizontal position;

- appreciate and reproduce correctly the proportions of objects;

- state well-founded value judgments. In order to determine the latter dimension, for example, students can identify elements of difference between two images.

Aptitudes can manifest even later, they can reach a high level of development, being in this case the result of persevering work, the acquisition of knowledge, and vast and systematic skills related to the activity or field in which it manifests. In the process of aptitude development, an important role is played by the development of interests. Interests are a strong stimulus for the acquisition of new knowledge, the enrichment of the psychic life, for the development of skills. The mediating factor between interests and skills is school success. When the child shows interest, he gets better results in the activity. New interests often develop, even skills to which they are linked. "After the age of 9, the correlations between interests and aptitudes begin to be more easily observed" (Șchiopu, 1967, p.254).

Aptitudes are made up of a multitude of processes and qualities between which complex relationships are established (interaction and interdependence with a character of mutual determination). Success in any activity cannot be 
ensured by the presence of an isolated aptitude but it requires the presence of several aptitudes, just as the absence of an aptitude cannot prevent the successful development of an activity. The ability of human thinking to find new solutions, to develop original ideas, to discover unknown things is called creativity. According to Popescu (2007) in order to obtain a creative phenomenon, the participation of the entire personality system is needed. The need to carry out an activity not only independently, but also creatively is formed from early childhood. When it comes to students, the activity through which something new, original is achieved is considered creative, expressing to some extent the individual inclinations, aptitudes and creative experience. Bonchiș (1998) considers that a creative student is characterized by the following aspects:

- quick understanding of the material presented, ability to structure and restructure information;

- confidence in one's own possibilities;

- independence from the opinion of adults;

- high level of aspiration, compared to that of the same age group;

- curiosity and involvement in the activity (p. 136).

Within the family and in school we must pursue the discovery of early endowment in those areas where native dispositions have a particularly important role, i.e., first in drawing and music, then in mathematics. The chances of success in choosing a career increase if the aptitudes are properly highlighted. In choosing the areas of activity, several aspects must be taken into account, such as: an aptitude can be used in several circumstances (for example, spatial aptitude is used by both a car mechanic and a designer) and career performance is not only given by a single skill, as well as a set of skills that compensate each other.

\section{Aptitudes for fine arts}

One can say about plastic education that:

- it has a significant role in stimulating attention, thinking, interest, skills;

- it promotes intellectual development and the formation of positive traits of will and character in students;

- it leads to the formation of artistic sense, of the ability to apply knowledge in practice, the development of creativity by orienting students to the new and unexplored;

- it uses strategies that make possible the transition from "knowing" to "doing", it develops logical thinking, observation, perseverance, courage.

Thus, the discovery and development of aptitudes specific to art education is an important factor in adjusting educational objectives and content. The artist's attitude towards his work, towards the world, his vision, the depth of his/her feelings is given by emotion. According to Luca (2010), some researchers classify artistic aptitudes into reflection-reproduction aptitudes and creative aptitudes, just as imagination is reproductive and creative. Others believe that there is a unique whole structure - the aptitudes for fine arts. V.I. Kirienko (according to Luca, 2010, p. 107) highlights a series of reflection-reproduction aptitudes, which he calls "plastic". These are: 
- the student's total perspective on an event, phenomenon, process;

- appreciation of deviations from the vertical and horizontal axis, from direction to landmark;

- estimating the proportions and the perspective ratios;

- evaluation of light relations;

- vision of color;

- visual memory.

They are conditioned by the tasks corresponding to the process of performing the composition and do not include emotion. On the other hand, the well-known Soviet psychologist A. G. Kovaliov (apud Luca, 2010, p. 108) examines the structure of aptitudes for fine arts as an interaction of the reproductive and creative components in the plastic activity. A. G. Kovaliov finds three component groups of aptitudes for plastic activity that best correspond to the specifics of drawing and painting:

- the main elements of skills (artistic imagination);

- landmark components (high natural sensitivity of the visual analyzer, special dexterity of the hands;

- background components, a certain emotional predisposition that occurs due to the existence of a high emotional sensitivity and is necessary for the artist at the time of creation.

The specific requirements for drawing and painting are found in the structure of the aptitudes for plastic activity developed by A. Kovaliov. Chris Kik (apud Luca, 2010, p. 108), based on the accumulated empirical facts, came to consider that artistic talent is a totality of various skills of plastic rendering of the idea, thus revealing the complex structure of skills for fine arts. Psychologists Roșca \& Zórgó (1972, p. 49) highlight the following components of artistic talent:

- fast, accurate and durable fixation of visual images of objects;

- the tendency to perceive the whole, with a lower inclination towards analysis;

- correct assessment of the deviation of the lines from the vertical or horizontal line;

- correct appreciation or reproduction of the proportion of objects, etc.

The German-born psychologist and pedagogue Ernst Meumann (ap ud Luca, 2010 , p. 109) investigated the causes of the inability to draw. Thus, he proposed to an experimental group to draw, from memory, the profile of the mountains, the church towers or the tools they frequently used. Then they had to make an oral description. The different results are explained by the poorly developed visual perception, which is not necessarily a physical defect but it appeared to be due to poor visual memory and lack of exercise of a graphic visual examination. $\mathrm{He}$ established that the inability to draw is due to: - inaccurate analytical visual perception; - inaccurate observation of the shapes and colors of objects; undeveloped visual memory; - not coordinating the memorized images with the movements performed to create a composition; - insufficient dexterity of the hands; $\bullet$ lack of knowledge of drawing schemes.

At the same time, Meumann (apud Luca, 2010, p. 110) establishes 10 plastic aptitudes: 
- the ability to distinguish shapes and colors; - correct distinction of images; visual memory (by practicing); - exact memorization of shapes and colors; • coordinating memory with hand movements; - imagination; - dexterity of the hands (by practicing); $\bullet$ the spirit of observation;

- free drawing, without templates; $\bullet$ creativity.

Psychologist N.C. Meier (1939, apud Luca, 2010, p. 111) considers that the following factors are an artistic criterion of talent: - hand dexterity; • perseverance and energy; • perception ease; - creative imagination. Researcher Ioan Berar (apud Luca, 2010, p. 112), in addition to aesthetic sensitivity and creativity, establishes the following graphic skills: - chromatic differentiation ability; • correct perception of proportions, sense of rhythm, shape and volume; • manual dexterity; • hand-eye coordination; - observation spirit; • thinking in images; • interest and attraction for the activity carried out; • perseverance. Of course, for a quality work of art one also needs (Luca, 2010, p. 114): • observation spirit; • imaginative memory; • operating with shapes and images in mind; - accuracy of hand movement; • combining the elements of perception in new images; - color differentiation; - visual perception of differences in dimensions; $\bullet$ visual acuity; $\bullet$ emotional sensitivity.

\section{Conclusions}

All people are born creative, in one way or another all are born and remain artists if they develop the power to conceptualize, to detach themselves from time and space, to analyze and make unsuspected associations. We all do this when we sleep, when we dream with our eyes open. In addition to all the skills presented above, artists - not only them, but also those who think like them - have something else: self-confidence, confidence in their work, they overcome their doubts, which leads to strengthening creativity. They do not seek permission to paint (Gompertz, 2016). They have the courage to support their opinions, to appreciate their work and to trust it.

Art class is about creativity. Students develop their practical and aesthetic sense, expressiveness and creative imagination, perception and understanding of the beauty of nature, art, life. The art education class is like a field where talents are sought, developed and cultivated. It is important to discover, to reveal the aptitude. But in order to become talented one depends on the teacher, based on how he/she chooses the methods and means favourable to the development of creativity and skills.

\section{References}

1. Andrieș, Alina, Maria, 2010, Testarea psihologică. Aptitudinile și inteligența, Editura Fundația România de Mâine, București

2. Bălan, Bogdan, 1999, Aptitudinile și importanța lor în activitatea școlară. În Cosmovici, Andrei, Iacob, Luminița, Psihologie Școlară, Editura Polirom, Iași

3. Bonchiș, Elena, 1998, Copilul și copilăria: o abordare psiho-pedagogică, Editura Imprimeriei de Vest, Oradea

4. Bonchiș, Elena, coord., 2000, Dezvoltarea umană-aspecte psihosociale, Editura Imprimeriei de Vest, Oradea 
5. Bonchiș, Elena, 2004, Psihologia copilului, Editura Universității Oradea, Oradea 6. Bronchart, Jean-Paul, 2006, Imaginație. În Doron, Roland, Parot, Francois, (coord.). Dicționar de psihologie (N. Cernăuțeanu et al., traducător), Editura Humanitas, București

7. Clegg, Brian, Brich, Paul, 2003, Creativitatea (D.L. Ilin, traducător), Editura Polirom, Iași

8. Davido, Roseline, 2017, Cum să-ți descoperi copilul prin desenele lui (A. Irimia, traducător), Editura Univers, București

9. Gompertz, Will, 2016, Gândește ca un artis. Gandeste ca un artist. Invata cu van Gogh, Picasso sau Andy Warhol cum sa fii creativ in orice domeniu, (L. Popovici, traducător), Editura Polirom, Iași

10. Hedges, Patricia, 2002, Personalitate și temperament. Ghidul tipurilor psihologice, Editura Humanitas, București

11. Luca, Adrian, 2010, Testare psihologică. Psihodiagnoza aptitudinilor şi inteligenţei

12. Aptitudini speciale, Editura CredisS, București.

13. Popescu, Gabriela, 2007, Psihologia creativității, Editura Fundația România de Mâine, București

14. Richelle, Mark, 2006, Abilitate. În Doron, Roland, Parot, Francois. (coord.). Dicționar de psihologie (N. Cernăuțeabu et al., traducător), Editura Humanitas, București.

15. Roșca, Al., Zorgo, B., 1972, Aptitudinile, Editura Ştiințifică, București

16. Zisulescu, Ștefan, 1971, Aptitudini și talente, Editura Didactică și Pedagogică, București

17. Zlate, Mielu, 2000, Fundamentele psihologiei, Editura Pro Humanitate, București

18. Aledrescu, Cristian, 2017, Aptitudinile. Consultată pe https://acpsihologie.ro/blog/aptitudinile/ la 1.12 .2020 ora 17.48 